Banegas et al. 2019, accepted manuscript, this is not the published version

\title{
A Gender Perspective in Initial English Language Teacher Education: An Argentinian Experience
}

Darío Luis Banegas, Lina Gabriela Jacovkis, Antonella Romiti

\begin{abstract}
In second language teacher education there is a gap in the literature concerning initial teacher preparation on gender and sexuality education. The aim of this study is to analyse the impact of a foreign language teaching module with a gender perspective on the education of a group of 30 student-teachers at an online initial English language teacher education programme in Argentina in 2018. Following an ecological approach to teacher research, data were gathered through surveys and student-teachers' completion of coursework. Overall, the studentteachers found the experience beneficial both regarding their personal development as citizens and future teachers, in terms of their increased awareness of gender matters and their ability to produce motivating language activities anchored in wider social practices which promote gender equality and diversity. The study includes implications for initial teacher education and curriculum development.
\end{abstract}

Keywords: teacher education; gender; sexual education; teacher research; professional practice

\section{Introduction}

Teacher education institutions are part of society and as such they are compelled to engage with the wider communities in which they are inserted. Teacher education plays a central role in instilling gender values in student teachers as there is a pressing need to prepare teachers as agents of change for diversity, inclusion, and social justice. Gender as a fluid construct cannot escape from teacher education, and language teacher education in this study, as student teachers need to be prepared to teach diverse learners in terms of gender and identity.

The imperative outlined above derives from critical pedagogy and a positionality of language as a social practice through which social justice can be sought (Freire 1970; Giroux 1997; Rocha Pessoa and de Urzêda Freitas 2012; Villacañas de Castro, Cano Bodi and Hortelano Montejano 2018). Drawing on critical theory, critical pedagogy and poststructuralism (Vavrus 2009), a pressing issue present in education is that of comprehensive sexual education linked to identity construction and transformative experiences through language (Sauntson 2018) and, in the case of this article, English language learning. While there have been advances in general education and TESOL (Teaching English to speakers of other languages) in particular regarding gender and TESOL (e.g., Appleby 2010), there is a paucity of studies which examine student-teacher preparation in initial English language teacher education (IELTE) programmes to address gender issues in their lessons not only through English language teaching but also beyond as educators responsible for the holistic growth of their learners. In other words, by 
preparing student teachers to reflect on and approach gender in language education, we are preparing them to understand and become aware of gender in language policy, curriculum, pedagogy, and assessment (Authors 2019) not only in English but also in other languages they may speak. Notwithstanding, there is a lacuna in the literature about how student-teachers receive formal and systematic preparation in IELTE programmes. Based on teacher research, this study addresses this lacuna by exploring a specific nine-month TESOL didactics module with a gender perspective at an IELTE programme in southern Argentina.

\section{Sexuality and Gender in TESOL}

Studies in (language) education have emphasised the importance of teachers being prepared to challenge heteronormativity and embrace a constructivist view of gender leaving behind gender binarism (male-female) and simplistic generalisations (Brochin 2019). Usually anchored in qualitative research, studies on gender in general education show evidence which supports that (1) preparing teachers through a gender perspective plays a fundamental role in helping LGBTIQ (lesbian, gay, bisexual, transgender, intersex and queer) learners and creating a supportive school climate (Collier, Bos and Sandfort 2015), (2) through teacher preparation, they can reflect on and challenge their own beliefs and personal experiences (Ollis, Harrison and Maharaj 2013) and become aware of their own identity construction as gendered beings (Robinson and Ferfolja 2008; Vavrus 2009).

In TESOL education, there is a well-cemented tradition of studying gender in second language classroom (Davis and Skilton-Sylvester 2004; Nelson 2009; Norton 2016; Norton and Pavlenko 2004; Norton and Toohey 2011) in the following interrelated areas usually based on sociocultural theory and critical pedagogy: (1) identity, (2) teaching materials, and (3) teacher education. Below we review recent studies in such interconnected areas.

Situated at the intersection of sexual identity and language learning, Evripidou (2018) examined the perceptions of a group of 16 primary EFL teachers' attitudes towards homosexuality as the author had noted teachers' refusal to explore homosexual identities in the language classroom. Drawing on focus groups, findings showed that the teachers believed that sexuality was not part of learning a foreign language as they connected (homo)sexuality only to intimate relationships between adults and disengaged from other social issues. The teachers' stereotypical and monolithic views of sexuality, gender, and identity led them to see primary school learners as asexual. Thus, the author concludes that TESOL teacher education should include formal and systematic preparation on sexual education from a lens that help them deconstruct heteronormativity and their own beliefs. This study confirms the pressing need to prepare foreign language teachers for comprehensive sexual education, identity positioning, and inclusive education as studies carried out in different setting show that learners with queer identities are claiming to be included in classroom interaction and overall language teaching practices (Moore 2016; Nguyen and Yang 2015).

TESOL educators may fail to connect sexuality with learning due to the heteronormativist approach entrenched in language teaching practices and materials (Pakuła, Pawelczyk and Sunderland 2015). For example, Ariyanto (2018) carried out critical discourse analysis on coursebooks for English language learning produced by the Indonesian Ministry of 
National Education. Results reveal something common across the publishing industry: gender stereotypes and gender bias through texts, visuals which do not represent any value for the potential discussion of gender, and the absence of tasks which could promote discussion and reflection on gender diversity and identity. As a reaction to this mainstream practice in the market, there are studies which examine materials development. In Japan, Miller and Endo (2016) developed lessons on gendernormativity using queer readings. The authors found that creating their own materials on such a topic allowed learners to become aware of gender diversity and how it intersects with different dimensions of society while developing their linguistic ability. In an action research study based in Colombia, Benavides Buitrago (2017) collected data through classroom observations, learners' task-driven conversations and learners' artifacts to explore the inclusion of gender topics through stories for the discursive construction of social identities among teenage learners. As in Miller and Endo (2016), the main finding was that learners became aware of gender and sexuality and shifted to understand humans as gendered beings. More recently, Govender (2019) investigated how a group of pre-service teachers at a South-African university designed their own teaching materials to promote the negotiation of gender and sexual diversity in the language classroom. Drawing on qualitative data, the author indicates that the pre-service teachers developed high levels of empowerment and agency as they could appropriate and enact critical pedagogies by providing their learners with context-responsive materials and topics absent in the language teaching publishing industry.

While the studies above usually include implications and suggestions for TESOL teacher education, the literature does not offer accounts of systematic teacher preparation for comprehensive sexual education. One exception is a study carried out at a Colombian university. Mojica and Castañeda Peña (2017) remark that foreign language teaching contexts must include a gender perspective. To this effect they created an optional module called Identity and Language Learning at a master's programme for English language teacher. Through data collected from in-class activities and questionnaires, the authors found that the teachers enrolled in the module could identify sexist discourses and behaviours in educational practices and teaching materials.

Given the lacuna in the TESOL teacher education literature about systematic teacher preparation on comprehensive sexual education, in this study we analyse the impact of a foreign language teaching module with a gender perspective on the education of a group of 30 student-teachers at an online four-year initial English language teacher education programme in Argentina.

\section{Comprehensive Sexual Education in Argentinian Teacher Education}

In 2006, Argentina's National Congress passed Law 26,150 to create a national programme of comprehensive sexual education (CSE) through which all learners have the right to sexual education in all educational institutions across the country. Readers should also be aware of other laws related to sexuality and gender in Argentina: (1) Law 26,485 (2009) to eradicate violence and harassment against women; (2) Law 26,618 (2010) to incorporate same-sex marriages as legal; (3) Law 26,743 (2012) to exercise the right to choose gender identity; and (4) Law 26,791 (2012) to fight against femicide and other crimes against women. 
Apart from the aforementioned laws, in the past few years Argentina has witnessed the rise of a feminist movement called Ni una Menos (Not One Woman Less), which campaigns against gender-based violence. Moreover, in 2018 there was a parliamentary debate around abortion which has held Argentinian society on its grip, and it has generated both the marea verde (Green Tide) of those in favour of abortion, as well as the Salvemos las dos vidas (Let's save the two lives) antiabortion movement. In this scenario, it is artificial, inadvisable and impossible that educational institutions turn both a deaf ear and a blind eye to the contexts in which they are set in (Morgade 2006).

By Law 26,150, CSE must be incorporated within the school curriculum of kindergarten, primary, and secondary education, and in teacher education. Concerning the latter, a set of curriculum guidelines were nationally agreed (Consejo Federal de Educación 2009) through which higher education institutions would offer mandatory modules, conferences, seminars and workshops (e.g., Bargalló and Lavari 2015) to prepare student-teachers to develop their practices under this new perspective. It was also agreed that teachers would be encouraged to align their subjects with a gender perspective. According to Román (2013), a gender perspective considers sexuality as one dimension of human life and promotes sexual, gender, emotional and relational wellbeing together with the construction of cultural horizons and citizenship. Publications attest to the challenges and opportunities derived from this move in kindergarten (Potenza and Vilalta 2016), primary (Morgade 2006; Morgade and Fainsod 2015), and higher education (Siderac 2015). Whatever the level, Bianco, Mariño and Re (2008) have identified three categories of attitudes found among teachers: those who have always talked about sexuality and reproductive health education in the classroom, even calling for parental involvement or open-mindedness; those whose silence is also a message, leading learner to either seek out poor information, or feel ashamed about it; and those who think that sexuality is only a biological and reproductive topic.

In terms of how learners and student-teachers are taught about comprehensive sexual education, initiatives and reports are scarce. Only two brief reports have been published: the addressing of gender construction with teenage learners in TESOL (Bobbio and Papini 2016), and the adoption of a gender perspective in university courses (Premat and Tortone 2018). This lacuna and emergent nature of comprehensive sexual education in practice calls for understanding how student-teachers can be prepared for discussing sex and gender in language education.

\section{Context of this Study}

This study took place at an online IELTE programme in 2018. It is a four-year programme where student-teachers graduate as teachers of English for kindergarten, primary, and secondary education. At any point in the programme they must complete a mandatory module on CSE delivered in Spanish to comply with Law 26,150. Some of the contents covered in the module are: discourses related to gender and sexualities, history of sexual education in Argentina, schools and pedagogies over bodies and sexualities, teenage pregnancy, sexual abuse and rights vulnerability, sexual transmission diseases, and discrimination and sexual diversity. 
In Year 3, student-teachers must take a two-term module (March-November) called Specific Didactics for English Language Teaching in Secondary Education. The aim of this module is to provide student-teachers with theoretical and practical tools to complete their practicum. Since 2013, contents covered in the module usually include: contextualised English language teaching, teaching English in Latin America and Argentina, approaches and methods, motivation, autonomy, cognitive skills and critical thinking, teaching and learning grammar and lexis, teaching and learning reading, writing, speaking and listening, materials development, testing and assessment, lesson planning, technology in language education, and CLIL (Content and language integrated learning). At the end of the 2017 academic year, Author 1 started to question his practices as tutor of the module regarding the inclusion of a gender perspective in TESOL didactics. For the 2018 academic year he decided to transform the module following this perspective and explicitly include comprehensive sexual education.

Module delivery included: online forums (Figure 1), activity analysis (Figure 2), discussions around a TED talk on equity and gender-based education, developing CLIL-driven lesson plans on topics such as gender violence, movements like Me Too or Ni Una Menos, gay families, sexual harassment at schools, or gender and identity among others, writing reflective texts on the challenges and opportunities behind lessons based on such topics, or suggesting activities to match linguistic aims such as "to describe facts/figures about gender violence using quantifiers".

Figure 1. Online forum.
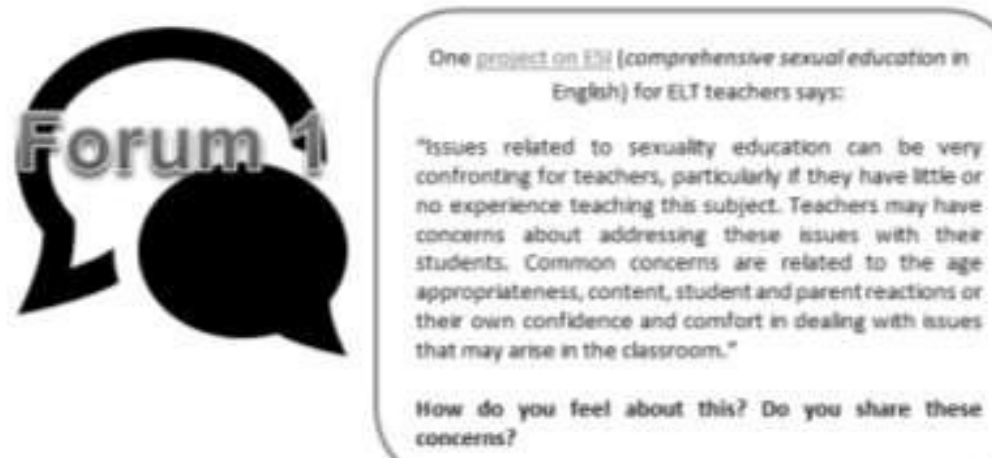

Figure 2. Activity analysis from a gender perspective. 

a. Look at the following set of four activities from a longer lesson plan. To what extent do they reflect the contents covered in this unit? What appronchesimethods and perspectives seem to be present here?

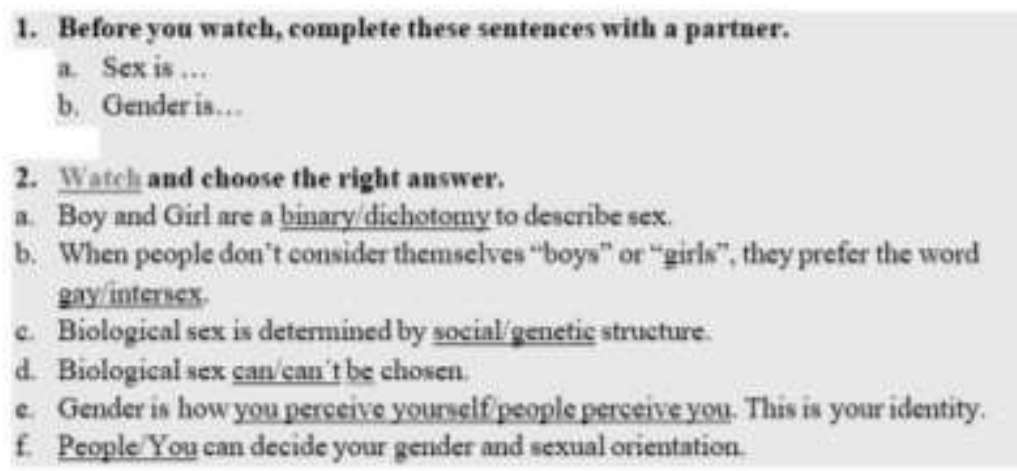

\section{Methods}

Framed in teacher research to explore Author 1's own practices (Borg 2013; Bullock and Smith 2015; Hanks 2017) to achieve professional development and situated knowledge, our research questions were:

- To what extent does a module on TESOL didactics following a gender perspective help student-teachers to consider a CSE approach in their future professional practices?

- What challenges and opportunities do student-teachers find in teaching English from a gender perspective?

Author 1 led the module, which was taken by 30 student-teachers ( 29 females and 1 male) in 2018. In terms of age, six were between 20-30, twenty between 31-40, and four were older than 41. Although this was an IELTE programme, only two student-teachers had no teaching experience, eight had 1-5 years of experience, fourteen had 6-10, and six had more than 16 .

At the beginning of the academic year in 2018 they were informed that their forum participations, assignments and exams would be used to examine the impact of the module in their development as future teachers. They all agreed to allow Author 1 to use their forum contributions, assignments and exams provided their anonymity was preserved. When the first draft of this article was finished, he circulated it among the student-teachers to have their validation and permission for potential publication. One student-teacher who identified one forum contribution as hers asked me to replace it for a reconstructed version she provided him by email on the grounds that her original post did not reflect her stance at the time. He complied with the request.

Since we wished to be as unintrusive as possible and respect student-teachers' time, an ecological approach (Edwards and Burns 2016; Stelma and Fay 2014) to data collection was adopted. Student-teachers' beliefs, perceptions and behaviours were collected through an online survey, online discussion forums, and activities such as developing lesson plans already included in the module units ${ }^{1}$ from March until November 2018. For this report, data come

\footnotetext{
${ }^{1}$ A complete set of activities through which data were collected and samples of student-teachers' activities can be retrieved from
} 
from the following instruments (Table 1). The instruments were used as the module developed since they were activities planned for learning. The activities were included in the different units the module contained.

Table 1. Activities as data collection instruments.

\begin{tabular}{|c|c|}
\hline Term & Activity/Data collection instruments \\
\hline \multirow{8}{*}{$\begin{array}{c}\text { Term } 1 \\
\text { (March- July) }\end{array}$} & A. An assignment with reflective questions. \\
\hline & $\begin{array}{l}\text { B. An assignment about analysing a lesson plan and modify it to include } \\
\text { CSE/ a gender perspective. }\end{array}$ \\
\hline & C. An assignment about analysing CSE-based activities \\
\hline & $\begin{array}{l}\text { D. An assignment about adapting activities from a coursebook to } \\
\text { include CSE/ a gender perspective. }\end{array}$ \\
\hline & E. An online forum about CSE and learner motivation. \\
\hline & F. A forum to design an activity with a CSE aim. \\
\hline & G. The development of a lesson plan on the topic of gender violence. \\
\hline & H. A forum to reflect on the links between CSE and values in TESOL. \\
\hline \multirow[t]{5}{*}{$\begin{array}{l}\text { Term } 2 \text { (August- } \\
\text { November) }\end{array}$} & $\begin{array}{l}\text { I. An assignment to reflect on published lessons and activities on } \\
\text { CSE in TESOL. }\end{array}$ \\
\hline & $\begin{array}{l}\text { J. The development of a lesson plan around the topic of identity and } \\
\text { gender. }\end{array}$ \\
\hline & K. The development of a lesson plan around a CSE topic. \\
\hline & L. A table to reflect on the lesson plans developed. \\
\hline & M. An activity to reflect on their beliefs around CSE and TESOL. \\
\hline
\end{tabular}

Data collected from the forums, and reflective questions were analysed through grounded theory (Hawker and Kerr 2016; Payne 2016). The data from each instrument was analysed independently to assess the influence of time and each unit in the module on the studentteachers' beliefs and practices. Data analysis as an iterative process initiated with open coding, and once a code set was established, data were re-analysed for confirmability and trustworthiness purposes. Axial coding was carried out to refine categories and led to selective or theoretical coding in order to produce conceptual categories for integration of findings. 
Through content analysis, lesson plans and assignments were examined to detect commonalities, patterns, recurrences, and student-teachers' progress in the incorporation of a CSE attitude in their TESOL education.

\section{Findings}

The data presented follow the course trajectory and development to reflect the natural history of the experience and concomitant research. Extracts include unaltered responses.

\section{Term 1: Beliefs}

Beliefs and reflections were gathered through activities/instruments $A, E$, and $H$, which provided insights on student-teachers' concerns, views on motivation and CSE in TESOL, and the relationship between values, mindfulness, and CSE. With regard to concerns, thematic analysis showed two salient categories: (1) student-teachers' feelings of uncertainty due to limited preparation and personal views, and (2) awareness of learners' attitudes towards CSE. As Extracts 1 and 2 illustrate, they all expressed that despite having little or no preparation they were willing to discuss CSE-related matters at school.

Feelings of uncertainty were explained by little preparation (E1), or restricted biomedical views on CSE (E2):

I haven't read what sexuality education entails now and we didn't learn much at school, and I wouldn't know where to begin, but I want to include it because students need more guidance and support particularly when their families can't help. (Anabella, E1)

I'm more for special classes with doctors and psychologists who come and give talks and students can talk to them if they want, without us teachers listening to them or even interfering. (Ana, E2)

In addition, uncertainty and little preparation demanded support from the community to counterbalance professional limitations:

I could include CSE but we need serious preparation to fight off our uncertainties, support and guidance from school heads and parents' knowledge that we will touch on CSE as the law says. When we approach sexual education, a mixture of thoughts and feelings arise: apprehension because it may ruin our job if we do it wrong, because some of the content which we are supposed to teach may come in conflict with our religious beliefs and our deepest convictions. And parents may come and complain because we're contradicting what they tell their kids at home. (Patricia, E3) 
Banegas et al. 2019, accepted manuscript, this is not the published version

Personal views explained student-teachers' reticence to include CSE in the language classroom. For example, two student-teachers expressed that CSE should not be part of the school curriculum because CSE was private (E4), and 20 expressed uncomfort as CSE in the language classroom could interpellate student-teachers' own sexualities and perspectives on gender equality (E5) as discussed in Maharaj (2013):

I have a perspective that may sound old-fashioned, but I believe that sexual education has to be discussed at home with the family. Teachers have too much on their plate already. Teachers can't be meddling with private matters or intimidate or expose students. (Corina, E4)

If we ask students, then we should be prepared to answer about our own sexuality. We should also be honest with ourselves and know that diversity exists and we have to accept it, to be able to teach sexual education. What I mean with this is that there are many homophobic teachers. (Paula, E5)

Concerning awareness of learner's attitudes to CSE learners' needs, all the student-teachers coincided that CSE could be a motivating topic to include at schools because it responded to teenagers' lives and therefore lessons with a gender perspective should be carefully planned (E6). This shows that despite personal reservations, they were eager to address CSE for their learners' holistic and socially relevant education.

CSE can be motivating for teenage students since they gain confidence in themselves, share personal experiences and express their ideas and beliefs. Through learning about sexuality, learners are able to understand social and cultural differences that shape the way society constructs gender and sexuality. Teachers can use their students' interests to work on identity, encouragement, and self-esteem. (Magalí, E6)

Only one student-teacher expressed scepticism about CSE as motivating:

I am not really sure if topics around sexual education and gender would be motivating for teenagers. Although they may talk about those issues with peers, they are usually reluctant to do so that freely with adults. (Catalina, E7)

As hoped in Sauntson (2018), in Term 1 the student-teachers showed eagerness to explore a gendered-perspective CSE in their teacher education and practices as they envisaged CSE as a critical and relevant area to imbue meaning to language education and citizenship education.

\section{Term 1: Practices}

Given the student-teachers' interests, Term 1 focused on providing opportunities to reflect on 
CSE and to design activities and lessons with a gender perspective. Activities/Instruments B, C, $D, F$, and $G$ explored student-teachers' practices at a design stage since the module under investigation did not entail implementing these activities.

Analysis of the activities and lessons showed that the student-teachers moved from broad to focused ideas in terms of topic or content but language work remained problematic as activities and lesson plans tended to revise prior language learnt. The result of studentteachers' completion of activity B showed that the student-teacher lacked the confidence to adapt a lesson plan to introduce a gender perspective. The lesson plan provided was on "A person I admire" with a language focus on adjectives to describe personality and phrases for introducing reasons. Of the 30 student-teachers, 16 received feedback encouraging them to be more specific as their ideas were broad and underdeveloped (Figure 3).

Figure 3. Feedback to a student-teacher.

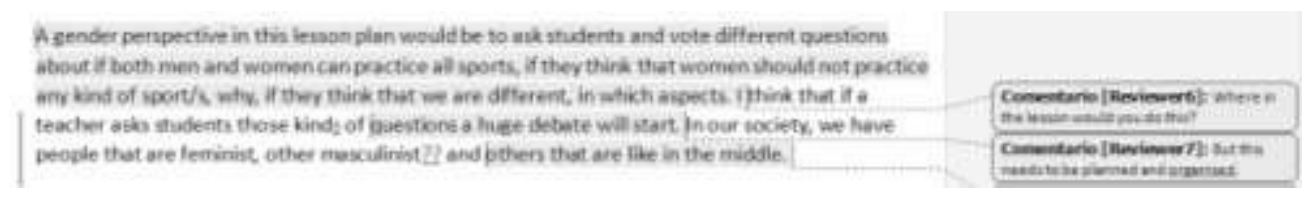

Only seven provided specific adaptations. For example, one student-teacher asked learners to describe a person who had fought for LGBTIQ rights, and five included texts on gender roles and change over time and tasks such as comprehension questions, statements to correct, tables for completion with information from the texts, and discussion questions. Two studentteachers did not submit this activity. Such practices contrasted with activity/instrument $E$ since in the forum the entire group commented that CSE could be included in CLIL lessons and that CSE could be an invaluable topic to "practise the four skills, grammar and vocab, and not just for revision but for presenting new language" (Erna, E8)

In activity/instrument $D$ the student-teachers were required to adapt an activity to introduce gender issues. On this occasion, only eight student-teachers' answers were assessed as unclear. In terms of topics, suggestions included gender and neutral language, gender equity, gender and likes, and gender and stereotypes. In terms of activities, there was a tendency to use role-play (Figure 4), read texts or quotes for discussion, analyse cartoons, or use a Venn diagram to compare and contrast people's interests.

Figure 4. Activity sample. 
Banegas et al. 2019, accepted manuscript, this is not the published version

\author{
Setting the activity: \\ The teacher tells the class that they are going to be working in pairs and calls the names by \\ groups, so the students can accommodate. \\ When all pairs are divided, the teacher hands out each group a story. The story has to have \\ mostly dialogues. This way, the teacher announces that who is a girl will have to play the male \\ role of the story and whoever is a boy will have to play the female role of the story. \\ The teacher should make very clear that they have to take it seriously and really get in the skin \\ of the character. \\ Running the activity: \\ The teacher must walk around the classroom listening to every group, without interfering \\ unless is required. \\ Closing the activity: \\ The teacher will ask the students if they liked the stories (why/ why not), group by group. \\ The teacher can ask the groups to raise their hands if they felt like the story was offensive for \\ males and same question for females.

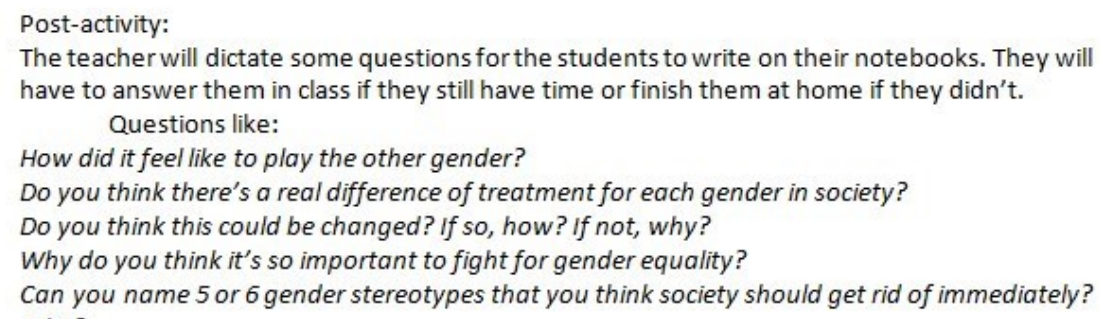

Activity/Instrument F signalled a significant change among the student-teachers. In this forum, they were required to think of an activity which responded to two aims: (1) to discuss violence against women in Argentina, and (2) to introduce quantifiers to describe facts and figures about gender violence in Argentina. Notably, all the activities were based on authentic sources of input such as flyers, campaigns, videos, pictures, official reports in either English or Spanish, and online newspaper articles. Unlike previous practices, all the activities integrated skills and were focused on the language aim provided. There was tendency $(\mathrm{N}=14)$ to design activities which combined reading a text and summarising key information (Figure 5), or discussing prompted by questions or statements. Speaking skills were found across all the activities suggested, whereas listening and writing skills were developed in seven activities respectively.

Figure 5. Text-based activity.

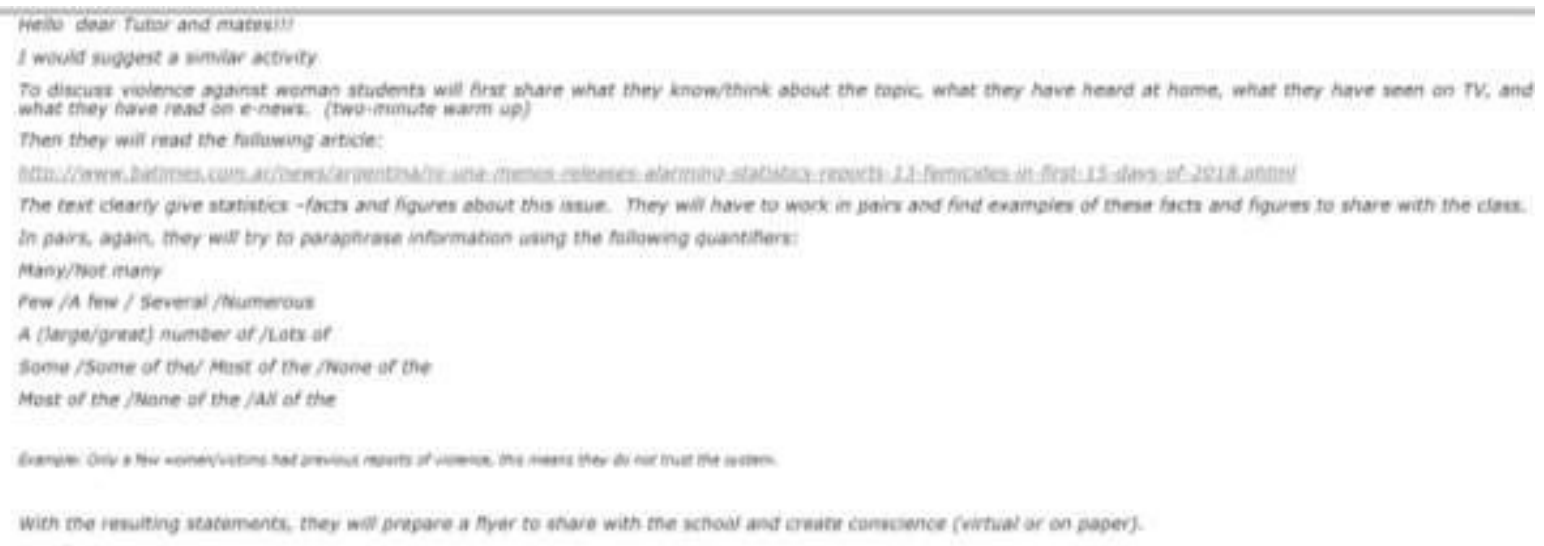


Term 1 included the design of a fully-fledged lesson plan (Activity/Instrument $\mathrm{G}$ ) around two aims: (1) discussing gender violence, and (2) introducing language for expressing opinions. Analysis of the lesson plans yielded the characteristics condensed in Table 4 (the numbers in brackets show recurrence).

Table 2. Lesson plans characteristics.

\begin{tabular}{|l|l|}
\hline \multicolumn{1}{|c|}{ Positive characteristics } & \multicolumn{1}{c|}{ Negative characteristics } \\
\hline $\begin{array}{l}\text { Use of varied sources of input (e.g., videos, } \\
\text { songs, film trailers, articles, pictures) (30) }\end{array}$ & Focus on content mostly (15) \\
\hline Language skills integration (25) & $\begin{array}{l}\text { Little language focus, no correlation to aim } 2 \\
(12)\end{array}$ \\
\hline $\begin{array}{l}\text { Activities sequenced in order of cognitive } \\
\text { complexity (20) }\end{array}$ & $\begin{array}{l}\text { The plan tended to be a revision lesson in } \\
\text { terms of content and language (12) }\end{array}$ \\
\hline Collaborative activities (23) & $\begin{array}{l}\text { Topic-specific vocabulary was introduced in } \\
\text { passing (12) }\end{array}$ \\
\hline Communicative activities (23) & $\begin{array}{l}\text { New language introduced through } \\
\text { decontextualised examples (9) }\end{array}$ \\
\hline $\begin{array}{l}\text { New structures (e.g., modals) introduced } \\
\text { through guided discovery or inductive } \\
\text { learning. (17) }\end{array}$ & Little scaffolding (7) \\
\hline
\end{tabular}

Term 1 showed student-teachers' eagerness to explore a gender perspective and CSE topics in TESOL practices. Although they acknowledged their limited experience and knowledge on this critical and innovative agenda in language education, they showed motivation and proactive behaviours to accept new challenges related to social justice, inclusion, and diversity.

\section{Term 2: Practices}

In Term 2, drawing on CLIL rationale and features included in the module, the student-teachers developed CSE-based lesson plans at the beginning of the term (Activity/Instrument J) and at the end in November 2018 (Activity/Instrument K). A comprehensive analysis of the first pool of lesson plans around the topic of gender and identity to introduce the present perfect tense revealed these recurrent positive features: (1) use of spidergrams to recover learners' prior knowledge or summarise ideas from input (videos, reading texts) ( $N=26),(2)$ deductive teaching, guided discovery, and language awareness for the presentation of new language items (structures and lexis) ( $\mathrm{N}=20)$, and (3) explicit vocabulary teaching through matching activities or organisers ( $\mathrm{N}=21$ ) to classify, for examples, adjectives to describe feelings and emotions of film characters. 
Notwithstanding, three recurrent challenges surfaced: (1) lack of lesson aims focused on content and language learning $(\mathrm{N}=18),(2)$ poor sequencing from lower-order to higher order thinking skills ( $\mathrm{N}=16),(3)$ misuse of authentic input (e.g., texts and videos) ( $N=12)$, and (4) teacher's questions as the most recurrent activity $(\mathrm{N}=12)$. While the lesson plans showed that feedback provided in Term 1 had been considered, aims continued to focus on content over language, which was generally treated in passing or only as revision. Furthermore, when the student-teachers included language aims, these were disconnected from the communicative and content purposes of the lesson (Figure 6).

Figure 6. Lesson plan aims.

\author{
Type of plan: Class \\ Duration: 90 minutes \\ Teaching points: Identity and gender. Present perfect. \\ Lesson aims: \\ -To improve speaking skills and language use strategies. \\ -To check reading comprehension. \\ -To practice identity related vocabulary. \\ -To introduce the present perfect tense. \\ -To improve listening skills and listening strategies. \\ -To practice and improve creative writing.
}

However, in the last lesson plan submitted findings were more positive. For this assignment the student-teachers could select the lesson topic from a range of CSE-related topics: Ni Una Menos ( $N=10)$, Gender and Discrimination ( $N=5)$, \#metoo ( $N=4)$, Women Must Be Mothers? $(\mathrm{N}=4)$, Time's Up Now $(\mathrm{N}=4)$, and Gender \& Colours $(\mathrm{N}=3)$. When asked to support their choices, the general perception was that all these topics helped raise learners' awareness and visualise current social issues. One student-teacher explained:

I chose this topic because I believe that it is very important that students know about different types of violence and that there is a current group fighting for women's rights. I also think that it helps them to realize that this is happening in any part of our country and even in others as well and that they themselves or people close to them can or could be suffering from some type of violence. (Anabella, E9)

These topics served as meaningful channels to introduce language items such as: passive voice, modals, phrasal verbs, conditional sentences, language for facts and opinions (Figure 7), comparatives and superlatives, and modals verbs.

Figure 7. Lesson plan extract. 
Banegas et al. 2019, accepted manuscript, this is not the published version

\begin{abstract}
"Almost the last activity I promise. I am going to ask you to find examples of opinions and facts in the text. Please make a list or a table or what is easier for you to understand with examples of both, facts and opinions. What is the difference and how can you realize when it is a fact or an opinion. Well, there are some words and phrases that show opinion and it is what someone thinks or believes, can be proved to be correct or incorrect. For example seem, indicate, suggest, believe, think, furthermore. adverbs of frequency (sometimes, usually, etc. help us to know that it is an opinion. Facts is what other people said, is something that can be proved, for example "The government has raised the bills of gas". You can do it in pairs if you want and then we check together'.

I will walk around checking and helping in case students need it.
\end{abstract}

\begin{tabular}{|c|c|}
\hline Opinions & Facts \\
\hline 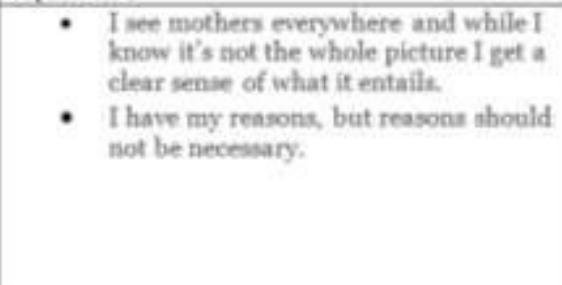 & $\begin{array}{l}\text { - The comernation is about children: } \\
\text { how many we bope to have, baby } \\
\text { names, would we nather a boy or a } \\
\text { girl? } \\
\text { - Jennifer Aniston lives a child-free life } \\
\text { and refuns to be pitied for it. "1 have } \\
\text { worked too hard in this life and this } \\
\text { career to be whittled down to a nad } \\
\text { childleas human," }\end{array}$ \\
\hline
\end{tabular}

In contrast to the first pool of lesson plans in the term, the last lesson plans (Activity/Instrument K) offered a greater number of recurrent positive features: (1) careful selection and use of pictures ( $N=27),(2)$ as Figure 8 illustrates, a wider range of activities and sources of input (e.g., trailers, short films, songs, quotes, flyers) through which content and language were introduced and practised through oral and written skills ( $N=25),(3)$ activities sequenced in order of cognitive and language load ( $N=21),(4)$ text adaptation ( $N=20),(5)$ clear aims for content and language learning $(\mathrm{N}=20)$. As Figure 8 shows, activities presented not only a focus of vocabulary but an adapted text which included instances of passive voice, the language aim of the lesson plan.

Figure 8.Video-based activities.

While watching: Now watch the following video and in pairs, complete the gaps with information from the video, both can take notes and then share the information. Then checked with the guesses you have done.

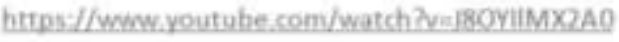

After watching: Work with a partner and complete the solutions for this issue proposed in the video. Choose the words from the box below:

\begin{tabular}{|llll|}
\hline $\begin{array}{l}\text { promotion } \\
\text { overheads }\end{array}$ & $\begin{array}{l}\text { productivity } \\
\text { flexible }\end{array}$ & $\begin{array}{l}\text { fair } \\
\text { training }\end{array}$ & shifts \\
\hline
\end{tabular}

Gender discrimination can be subdued by flexble working measures. By maximizing

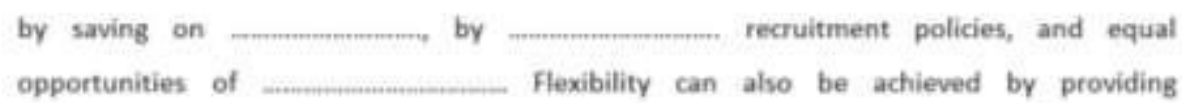
opportunities, by maternity/paternity benefits and work 
As part of this lesson plan, the student-teachers were asked to comment on achievable aspects and challenges. Concerning achievable aspects, all the student-teachers expressed that selecting authentic materials was easy; however, the most recurrent challenge was adapting such materials, particularly reading texts, and creating activities to exploit those materials to achieve their content and language aims.

\section{Term 2: Final thoughts}

In Activity/Instrument $M$ the student-teachers were asked to reflect on personal attitudes towards CSE after module completion. Thematic analysis of the 30 responses provided that 29 student-teachers welcomed the inclusion of a gender perspective in the didactics module. Only one student-teacher showed a different perception in a rather cryptic answer:

I have to say that I am a woman, and I love being a woman. I believe in God, and in the family as the cell of our society. With respect, love, empathy, and education we can change the world. (Romualda, E10)

When asked to offer an elaborated response, Romualda declined to do so. Our interpretation is that she had concerns with the gender perspective the module had adopted and this was her less confrontational attitude to express her view. In her answer she seems to reinforce her gender and sexual identity together with her Christian beliefs as a manner, possibly, to challenge the topics included in the module.

The other responses showed that the module had helped 29 student-teachers to strengthen $(\mathrm{N}=23)$ or change their views on CSE in education $(\mathrm{N}=6)$ positively at a personal and at a professional level.

At a personal level, two major categories emerged: (1) personal experiences with abuse as challenges for teaching, and (2) social awareness development through CSE. For example, Celina expressed that the module helped her overcome her own lived experiences and transform them into a learning opportunity for herself and her learners:

I myself have been in an abusive relationship, so did my mother. I've been educating myself on this matter. Ni Una Menos is a movement that I feel represents and supports women everywhere, of any social context. This wasn't a very easy topic for me to work on but I took it as a challenge because I want the coming generations to be better prepared. (Celina, E11)

In relation to social awareness development through CSE, eight student-teachers coincided that they had developed acute awareness of "what is happening at schools, in our cities" and that therefore these issues had to be included and addressed in education. A recurrent perception was that as responsible citizens, it was their duty to help learners increase their awareness and celebrate diversity in all its manifestations. As one student-teacher put it: 
It's not about English. It's about helping our kids feel safe, embrace diversity, and develop respect and be able to detect if they or others are the victims of abusive behaviour because of gender. (Mariana, E12)

At a professional level, student-teachers perceived an increase in their (1) confidence, (2) professional awareness, (2) need to be educated in CSE, and (3) refined perceptions of CSE and its potential in (language) education.

Those student-teachers ( $\mathrm{N}=12)$ who associated the impact of the module with their teaching confidence expressed that they had gained new pedagogical tools, strategies, and skills for materials development. Through CSE they had become more confident in developing CLIL lessons, which, in some cases, they had even implemented in the practicum:

Because the module boosted my confidence, I implemented a couple of lessons on gender and identity in my teaching practicum. It was so positive! The students were engaged and paid attention and were willing to use English because they so much wanted to talk about this topic. (Anabella, E13)

Professional awareness refers to the transformative journey experienced by the studentteachers and how they realised of the need to include CSE in TESOL as an instantiation of CLIL. As one student teacher put it:

I believe that all the activities we completed have helped me understand that it is essential to include CSE issues in secondary education. (Marisa, E14)

This professional awareness led 25 the student-teachers to remark the necessity to engage in professional development opportunities to tackle CSE with the responsibility it deserves:

It's important that we raise awareness on CSE, gender, cultural practices, but as teachers we must take course on CSE in order to be prepared to include it in our lessons. And we can also work interdisciplinary with psychologists, etc., to get more training. (Ema, E15)

Above all, CSE emerged as a potent content to include in (language) education. According to the 21 student-teachers, CSE is a right, a need, and a must to raise learners' awareness and to help them not only to develop English language proficiency but also to develop their critical thinking skills. Clara's extract illustrates this general perception:

Adding CSE to our lessons makes learning English meaningful. Students will want to participate, they will be motivated and it may even be liberating for them to 
Banegas et al. 2019, accepted manuscript, this is not the published version

talk about this in English or a mix of Spanish and English. Students need to be prepared to make informed decisions about their health, their body, so teaching CSE will allow students develop critical thinking. (Clara, E16)

According to the data gathered in Term 2, student-teachers evolved from lack of confidence to feelings of empowerment and awareness of the language and wider benefits of imbuing TESOL with a gender perspective through which critical thinking and diversity could be reinforced and secured.

\section{Discussion}

In this section we answer our research questions under the light of the theoretical background and findings presented above. In the first research question we asked ourselves about the extent to which a module on TESOL didactics following a gender perspective may help studentteachers to consider a CSE approach in their future professional practices.

Despite some reservations and concerns (E1-4, 10), the module succeeded in helping student-teachers consider CSE as a meaningful topic through which English could be taught. Following a CLIL approach, the module initiated the innovative practice of regarding CSE as content for English language learning. Being explicitly exposed to reflections and preparation on CSE in TESOL prompted the student-teachers to consider CSE as relevant content not only school-wise but more importantly social-wise (E5, 9, 12, 16; Figures 4-5).

Through a gender perspective in TESOL didactics, the student-teachers explored for the first time the possibility of designing and adapting materials, activities, and complete lesson plans which revolved around aspects of sexuality and gender as social constructs (Figures 1-8, Table 4). Initial uncertainties due to little preparation (E1) and institutional support (E3) did not impede them to see the motivation potential that CSE could offer among teenage learners (E6) embedded in complex social relations inside and outside schools. Driven by their awareness of learners' attitudes to CSE (E6-7), the module contributed to studentteachers' understanding of the social justice value behind the inclusion of a gender perspective in foreign language education $(E 6,9,12,15,16)$. This new understanding present throughout the module helped them to design lessons and materials which were socially and linguistically relevant since the lessons integrated content and language aims and the activities invited learners not only to reflect on language use, structures, and vocabulary, but also to share their views, identities, and experiences through a foreign language (E 13, 14, 16, Table 4).

The module allowed student-teachers to consider a CSE approach in their future professional practices from both a personal and professional stance. From a personal stance, findings show that CSE was generally welcomed given its potential to enhance social awareness on gender diversity and equity beyond language education (E12) and school life even when it could challenge personal views or unearth personal stories of abuse (E11). In this regard, we suggest that teacher education modules which adopt a gender perspective promote personal and social empowerment to raise teachers' voices and seek spaces to discuss personal 
trajectories and experiences. As future professionals, the student-teachers also noted an increase in (1) their confidence to include CSE in language teaching (E13) through a CLIL approach, (2) professional awareness on how to exploit CSE (E14), and (3) reflections around the need for continuing education in CSE in TESOL (E15). Such findings extend Sauntson's (2018) views as a language pedagogy module can transform the symbiotic personal and professional identities of future teachers as they begin to see themselves as capable of exploring territories that had been envisaged as obstacles prior to the module.

Through the second research question we set out to explore the challenges and opportunities that student-teachers may find in teaching English from a gender perspective. In terms of challenges, some student-teachers, as discussed above, found that teaching English from a gender perspective would challenge their own beliefs, perceptions, formal preparation, and own as well as other colleagues' sexuality $(E 5,10)$. Focusing on language pedagogy, the findings show that throughout the module the student-teachers struggled with teaching and learning aims which integrated content and language learning (Figure 6), materials exploitation, and sequencing activities from less to more demanding cognitive load (Figure 3). We reason that these challenges were the result of the novelty of the gender perspective adopted in the module and student-teachers' first encounters with CSE in TESOL pedagogies. On the other hand, they found opportunities for language skills integration, collaborative work, meaningful language learning, CLIL implementation, and the use of varied activities coupled with authentic and adapted sources of input (Figures 4 and 8).

While there are experiences on the discussion of gender and sexuality in (language) teacher education, we believe that this experience was relevant because it was systematic, over an entire academic year, and ingrained in a module that offered explicit links between English language learning and teaching processes through the adoption of a gender perspective. The module empowered the student-teachers to reflect on their own beliefs and explore CSE in language teaching for learners' benefit as critical citizens in societies that need to incorporate inclusivity and diversity in their daily social practices beyond the rhetoric and discourse of sexuality and gender education. Student-teachers' answers throughout both terms reflect Bianco et al.'s (2008) attitudes towards CSE: (1) those who talk about CSE; (2) those who do not, and (3) those who think it is only biological and should be in the hands of doctors and psychologists. However, our study shows that these attitudes could be reconsidered and challenged through systematic work and collaborative activities online (but see E10).

In the introduction and literature review sections we highlighted the paucity of studies at the intersection of initial language teacher education and CSE. We believe that this qualitative and sociocultural-based study contributes to our knowledge of sexuality in language teacher education because through a one-year module we have synthesised the TESOL literature on sexuality and gender and moved forward by investigating the impact of support provision and overall preparation in a module which combined language teaching with a gender perspective with the aim of naturalising and articulating CSE throughout a teacher education programme. As recommended in Evripidou (2018), our study shows that through systematic support in TESOL modules which promote social justice from a gender perspective, student-teachers develop higher levels of reflection and awareness of CSE. Furthermore, they 
can translate a gender perspective into their own future teaching practices as materialised in lesson plans and materials so that learners can find a meaningful space to discuss sexuality and identity in a wider context. The module under investigation was not optional as it was the case in Mojica and Castañeda Peña (2017); it was a core mandatory module aimed at building pedagogical content knowledge in language teacher education. In so doing, future teachers can receive systematic support to appropriate and enact critical pedagogies (Govender 2019) that mitigate homophobia still prevalent in society (Brochin 2019) and systematise diversity in language education.

\section{Conclusion}

Although our findings are based are limited to one experience and circumscribed to Argentinian laws, it may be agreed that when student-teachers explore a gender perspective, confidence and empowerment exceed the classroom and allow them to engage in CSE as critical citizens in world where social justice, equality, and diversity are often under attack. The findings show that the inclusion of sexuality education in language teacher education proved to be useful for more than one reason. First of all, because the self-representation of studentteachers changed throughout the development of the activity: student-teachers stated that they felt more able to include CSE content in the classroom. On the other hand, they stated that their own view of CSE changed from a more biologically-oriented approach to a more holistic one, in which they understand that a gender perspective is not just a legal right of students, but also that it improves critical thinking and diversity in the classroom.

In this experience, initial teacher education in general, becomes a powerhouse for comprehensive and holistic professional development which engages future teachers and teacher educators in addressing issues which pertain to a wider agenda interested in developing critical citizenship and human rights for all. Thus, teacher education programmes and curriculum development plans should work towards the systematic, mandatory, and normalised inclusion of CSE for teachers' and learners' benefit and society in general to further address the intersection of sexuality as a cultural construct from a gender perspective and education for inclusion and diversity.

Future research could investigate teachers' situated practices within a gender perspective in language education and general education at large and thus examine how teachers move from planning to implementation. Future research should also give attention to how CSE preparation in teacher education programmes affects teachers' situated practices after graduation. Findings from such research can provide insights for the development of in-service courses. Last, research could examine the role of school authorities and parents in the delivery of CSE in primary and secondary language education. Such possible studies could adopt a teacher research framework and incorporate methods such as narrative inquiry or ethnography to arrive at thick descriptions of CSE in practice.

\section{Compliance with Ethical Standards:}


Banegas et al. 2019, accepted manuscript, this is not the published version

Funding: Not applicable.

Conflict of Interest: Author A declares that he/she has no conflict of interest. Author B declares that he/she has no conflict of interest. Author $\mathrm{C}$ declares that he/she has no conflict of interest.

Ethical approval: All procedures performed in studies involving human participants were in accordance with the ethical standards of the institutional and/or national research committee and with the 1964 Helsinki declaration and its later amendments or comparable ethical standards.

Informed consent: Informed consent was obtained from all individual participants included in the study.

\section{References}

Appleby, R. (2010). ELT, gender and international development: Myths of progress in a neocolonial world. Bristol: Multilingual Matters.

Ariyanto, S. (2018). A portrait of gender bias in the prescribed Indonesian ELT textbook for junior high school students. Sexuality and Culture, https://doi.org/10.1007/s12119018-9512-8

Bargalló, M. L., \& Lavari, M. (Eds.). (2015). Educación sexual integral en la Argentina: Voces desde la escuela. Buenos Aires: Ministerio de Educación.

Benavides, C. (2017). EFL students' social identities construction through gender-based short stories. Colombian Applied Linguistics Journal, 19(1), 11-21. doi:10.14483/calj.v19n1.10641

Bianco, M., Mariño, A., \& Re, M. I. (2008). Docentes y educación sexual integral: Un papel en constante construcción. Buenos Aires: Fundación Para Estudio e Investigación de la Mujer (FEIM).

Bobbio, S., \& Papini, R. (2016). An interdisciplinary and intercultural approach to the construction of gender. In D. L. Banegas, M. López-Barrios, M. Porto \& A. Soto (Eds.), ELT as a multidisciplinary endeavour: Growing through collaboration Selected papers from the 41st FAAPI Conference (pp. 7-17). San Juan: ASJPI.

Borg, S. (2013). Teacher research in language teaching: A critical analysis. Cambridge: Cambridge University Press.

Brochin, C. (2019). Queering bilingual teaching in elementary schools and in bilingual teacher education. Theory Into Practice, 58(1), 80-88. doi:10.1080/00405841.2018.1536917

Bullock, D., \& Smith, R. (Eds.). (2015). Teachers research! Faversham: IATEFL. 
Banegas et al. 2019, accepted manuscript, this is not the published version

Collier, K. L., Bos, H. M. W., \& Sandfort, T. G. M. (2015). Understanding teachers' responses to enactments of sexual and gender stigma at school. Teaching and Teacher Education, 48, 34-43. doi: 10.1016/j.tate.2015.02.002

Congreso de la Nación Argentina. (2006). Ley 26.150: Programa nacional de educación sexual integral. Buenos Aires.

Congreso de la Nación Argentina. (2009). Ley 26.485. Buenos Aires.

Congreso de la Nación Argentina. (2010). Ley 26.618. Buenos Aires.

Congreso de la Nación Argentina. (2012). Ley 26.743. Buenos Aires.

Congreso de la Nación Argentina. (2012). Ley 26.791. Buenos Aires.

Consejo Federal de Educación. (2009). Lineamientos curriculares para la educación sexual integral. Buenos Aires: Ministerio de Educación.

Davis, K. A., \& Skilton-Sylvester, E. (2004). Looking back, taking stock, moving forward: Investigating gender in TESOL. TESOL Quarterly, 38(3), 381-404. doi:10.2307/3588346

Edwards, E., \& Burns, A. (2016). Language teacher-researcher identity negotiation: An ecological perspective. TESOL Quarterly, 50(3), 735-745. doi:10.1002/tesq.313

Evans, M. P. (2013). Educating preservice teachers for family, school, and community engagement. Teaching Education, 24(2), 123-133. doi:10.1080/10476210.2013.786897

Evripidou, D. (2018). The interrelationship among sexual identity, learning, and sexualisation: Primary EFL teachers' attitudes in Cyprus. TESOL Quarterly, 52(4), 1062-1072. doi:10.1002/tesq.433

Freire, P. (1970). Pedagogia do oprimido. New York: Herder \& Herder.

Giroux, H. (1997). Escritura y pensamiento crítico en los estudios sociales. Los profesores como intelectuales: Hacia una pedagogía crítica del aprendizaje. Barcelona: Paidós.

Govender, N. N. (2019). Negotiating gender and sexual diversity in English language teaching: "Critical"-oriented educational materials designed by pre-service English teachers at a South African university. In M. López-Gopar (Ed.), International perspectives on critical pedagogies in ELT (pp. 125-150). Basingstoke: Palgrave.

Hanks, J. (2017). Integrating research and pedagogy: An exploratory practice approach. System, 68, 38-49. doi:10.1016/j.system.2017.06.012

Hawker, S., \& Kerr, C. (2016). Doing grounded theory. In E. Lyons \& A. Coyle (Eds.), Analysing qualitative data in psychology (pp. 147-160). London: Sage.

Miller P. C., \& Endo H. (2016). Introducing (a)gender into foreign/second language education. In sj Miller (Ed), Teaching, affirming, and recognizing trans and gender creative youth: $A$ queer literacy framework (pp. 163-184). London: Palgrave Macmillan. 
Banegas et al. 2019, accepted manuscript, this is not the published version

Mojica, C. P., \& Castañeda-Peña, H. (2017). A learning experience of the gender perspective in English teaching contexts. PROFILE Issues in Teachers' Professional Development, 19(1), 139-153. doi:10.15446/profile.v19n1.56209.

Moore, A. R. (2016). Inclusion and exclusion: A case study of an English class for LGBT learners. TESOL Quarterly, 50(1), 86-108. doi:10.1002/tesq.208

Morgade, G. (2006). Educación en la sexualidad desde el enfoque de género: Una antigua deuda de la escuela. Novedades Educativas 184, 40-44.

Morgade, G., \& Fainsod, P. (2015). Convergencias y divergencias de sentido en los talleres de educación sexual integral de la formación docente. Revista del IICE, 38, 39-62.

Nelson, C. D. (2009). Sexual identities in English language education. New York, NY: Routledge.

Nguyen, H. \& \& Yang, L. (2015). A queer learner's identity positioning in second language classroom discourse. Classroom Discourse, 6(3), 221-241. doi: 10.1080/19463014.2015.1093952

Norton, B. (2016). Identity and language learning: Back to the future. TESOL Quarterly, 50(2), 475-479. doi:10.1002/tesq.293

Norton, B., \& Pavlenko, A. (2004). Addressing gender in the ESL/EFL classroom. TESOL Quarterly, 38(3), 504-514. doi:10.2307/3588351

Norton, B., \& Toohey, K. (2012). Identity, language learning, and social change. Language Teaching, 44(4), 412-426. doi:10.1017/S0261444811000309

Ollis, D., Harrison, L., \& Maharaj, C. (2013). Sexuality education matters: Preparing pre-service teachers to teach sexuality education. Burwood: Deakin University.

Pakuła, Ł., Pawelczyk, J., \& Sunderland, J. (2015). Gender and sexuality in English language education: Focus on Poland. London: British Council.

Payne, S. (2016). Grounded theory. In E. Lyons \& A. Coyle (Eds.), Analysing qualitative data in psychology (pp. 119-146). London: Sage.

Potenza, E., \& Vilalta, C. (2016). Educación sexual integral y educación visual en el nivel inicial. Paper presented at the III Jornadas de Formación Docente Desafíos y tensiones de la formación docente en los actuales escenarios. Universidad Nacional de Quilmes, Bernal, Argentina.

Premat, L., \& Tortone, N. (2018). Redefining ESP teaching practice: Reading comprehension from a gender perspective. In D. L. Banegas, M. López-Barrios, M. Porto \& M. Waigandt (Eds.), Adapting to meet diverse needs in ELT: Selected Papers from the 43rd FAAPI Conference (pp. 68-76). Río Gallegos: APISC.

Robinson, K. H., \& Ferfolja, T. (2008). Playing it up, playing it down, playing it safe: Queering teacher education. Teaching and Teacher Education, 24, 846-858. doi:10.1016/j.tate.2007.11.004 
Banegas et al. 2019, accepted manuscript, this is not the published version

Rocha Pessoa, R. R., \& de Urzêda Freitas, M. T. (2012). Challenges in critical language teaching. TESOL Quarterly, 46(4), 753-776. doi: 10.1002/tesq.46

Román, C. (2013). ESI (Educación Sexual Integral): Del marco teórico a la puesta en práctica por estudiantes de la formación docente. Paper presented at the VII Jornadas Nacionales sobre la Formación del Profesorado. 12-14 September, Universidad Nacional de Mar del Plata, Argentina.

Sauntson, H. (2018). Language, sexuality and education. Cambridge: Cambridge University Press.

Siderac, S. (2015). Teacher training and comprehensive sexuality education at Unlpam. Entramados: Educación y Sociedad, 2(2), 75- 81.

Stelma, J., \& Fay, R. (2014). Intentionality and developing researcher competence on a UK master's course: An ecological perspective on research education. Studies in Higher Education, 39(4), 517-533. doi: 10.1080/03075079.2012.709489

Vavrus, M. (2009). Sexuality, schooling, and teacher identity formation: A critical pedagogy for teacher education. Teaching and Teacher Education, 25, 383-390. doi:10.1016/j.tate.2008.09.002

Villacañas de Castro, L. S., Cano Bodi, V., \& Hortelano Montejano, A. (2018). Teaching English as a non-imperial language in an underprivileged public school in Spain. TESOL Quarterly, doi: doi:10.1002/tesq.442

\section{WORD COUNT:}

